\title{
FERMENTATION OF IRRADIATED SUGARCANE MUST
}

\author{
André Ricardo Alcarde ${ }^{1 *}$; Júlio Marcos Melges Walder ${ }^{2}$; Jorge Horii ${ }^{1}$ \\ ${ }^{1}$ USP/ESALQ - Depto. de Agroindústria, Alimentos e Nutrição, C.P. 9 - 13418-900 - Piracicaba, SP - Brasil. \\ ${ }^{2}$ USP/CENA - Lab. de Irradiação de Alimentos e Radioentomologia, C.P. 96 - 13400-970 - Piracicaba, SP - \\ Brasil. \\ *Corresponding author < aralcard@esalq.usp.br>
}

\begin{abstract}
Bacillus and Lactobacillus are bacteria that usually contaminate the ethanolic fermentation by yeasts and may influence yeast viability. As microorganisms can be killed by ionizing radiation, the efficacy of gamma radiation in reducing the population of certain contaminating bacteria from sugarcane must was examined and, as a consequence, the beneficial effect of lethal doses of radiation on some parameters of yeast-based ethanolic fermentation was verified. Must from sugarcane juice was inoculated with bacteria of the genera Bacillus and Lactobacillus. The contaminated must was irradiated with 2.0, 4.0, 6.0, 8.0 and 10.0 $\mathrm{kGy}$ of gamma radiation. After ethanolic fermentation by the yeast (Saccharomyces cerevisiae) the total and volatile acidity produced during the process were evaluated; yeast viability and ethanol yield were also recorded. Treatments of gamma radiation reduced the population of the contaminating bacteria in the sugarcane must. The acidity produced during the fermentation decreased as the dose rate of radiation increased. Conversely, the yeast viability increased as the dose rate of radiation increased. Gamma irradiation was an efficient treatment to decontaminate the must and improved its parameters related to ethanolic fermentation, including ethanol yield, which increased $1.9 \%$.
\end{abstract}

Key words: bacteria, gamma radiation, yeast

\section{FERMENTAÇÃO DE MOSTO DE CALDO DE CANA-DE-AÇÚCAR IRRADIADO}

\begin{abstract}
RESUMO: Bactérias dos gêneros Bacillus e Lactobacillus são microrganismos que normalmente contaminam a fermentação alcoólica realizada por leveduras. Estas bactérias podem causar queda da viabilidade das leveduras. Como a radiação ionizante pode eliminar microrganismos, estudou-se o efeito da radiação gama na redução da população de bactérias contaminantes do mosto de caldo de cana-de-açúcar e verificaram-se seus efeitos sobre alguns parâmetros da fermentação alcoólica. O mosto de caldo de cana-de-açúcar foi inoculado contaminado com bactérias dos gêneros Bacillus e Lactobacillus, e após irradiação com doses de 2,0; 4,0; 6,0; 8,0 e 10,0 kGy de radiação gama, foi efetuado a contagem da população das bactérias. Leveduras Saccharomyces cerevisiae foram inoculadas no mosto irradiado para realizarem a fermentação alcoólica. Após a fermentação, foram determinados a acidez total e a acidez volátil do vinho, a viabilidade das células de levedura e o rendimento da fermentação. $O$ tratamento com radiação gama reduziu a população das bactérias contaminantes do mosto. A acidez produzida durante a fermentação diminuiu com o aumento das doses de radiação aplicadas ao mosto, e viabilidade das leveduras aumentou com o aumento das doses de radiação. A irradiação gama foi um eficiente tratamento para descontaminar o mosto de caldo de canade-açúcar e melhorar os parâmetros da fermentação alcoólica, aumentando o rendimento da fermentação em $1,9 \%$.

Palavras-chave: bactéria, radiação gama, levedura
\end{abstract}

\section{INTRODUCTION}

Brazil has developed a technology for the production of carburant ethanol to substitute gasoline as fuel. Carburant ethanol is an alternative fuel produced by the fermentation of sugarcane juice, a renewable raw material. It has been used in Brazil for more than 25 years with impressive results, specially concerning ecological aspects related the reduction of the emission of pollutants and economical aspects, related to savings on petroleum importation (Alcarde et al., 2001).
Bacteria of the genera Bacillus and Lactobacillus are the microorganisms that most contaminate ethanolic fermentation (Rosales, 1989; Gallo \& Canhos, 1991). These bacteria excrete organic acids and toxins that compete with yeasts during ethanolic fermentation. Consequently, the acidity of the must increases and the growth of the yeast is inhibited (Bevan \& Bond, 1971; Amorim \& Oliveira, 1982; Alves, 1994). According to Oliva-Neto \& Yokoya (1997) the high acidity of the must is the main factor causing death of yeast cells during ethanolic fermentation. As a consequence of the inhibi- 
tion of the fermentative yeast, ethanol yield may decrease (Amorim et al., 1981; Alterthum et al., 1984; Khan \& Hoq, 1990).

Antibiotics and concentrated sulphuric acid are the traditional products used by the ethanolic industries to reduce microbial cohntamination of must. Antibiotics are expensive and the use of such products is restricted by the factor cost-benefit. Currently, the ethanolic industry has considered acceptable bacterial loads of musts circa $10^{5} \mathrm{CFU} \mathrm{mL} \mathrm{m}^{-1}$ (colony forming units per $\mathrm{mL}$ ), and it has not been economically viable to go below this level.

Therefore, the use of ionizing radiation may be an alternative for the decontamination of sugarcane must. Ionizing radiation can change the cellular DNA, affecting the cellular functions and inducing the death of the cells (Urbain, 1986). The objective of this study was to verify the influence of gamma radiation in reducing the population of certain contaminating bacteria present in sugarcane must and, as consequence, assess its reflex on acidity of the fermentation medium, viability of the yeast and ethanol yield.

\section{MATERIAL AND METHODS}

The following cultures of bacteria isolated from sugarcane fermentative processes for the production of ethanol, were tested: Bacillus subtilis, Bacillus coagulans, Lactobacillus plantarum and Lactobacillus fermentum. Bacteria of the genus Bacillus were reactivated separated in broth glucose-yeast extract-tryptone (PCA Difco 0479) and those of the genus Lactobacillus were reactivated separately in broth MRS (MRS Difco 0881-01-3). After incubation at $32^{\circ} \mathrm{C}$ for $24 \mathrm{~h}$, cultures were subcultured again into the respective broths and incubated at $32^{\circ} \mathrm{C}$ for $48 \mathrm{~h}$.

In separate experiments, each bacterial culture was inoculated into sterile must. A parallel experiment with a mixed bacterial culture, prepared by mixing 2.0 $\mathrm{mL}$ of the suspension of each reactivated bacterium was also carried out. Another experiment was carried out using the sugarcane juice with its own microbial flora.

The must was prepared from sugarcane juice obtained from the milling of peeled and cleaned canes. The sugarcane juice was filtered through cotton, boiled for 20 min and filtered through filter paper to remove gross impurities, diluted to $5 \%$ of total reducing sugars (TRS), and sterilized at $121^{\circ} \mathrm{C}, 1 \mathrm{~atm}$, for $20 \mathrm{~min}$. This low percentage of TRS in the must, approximately a third of that used in the industry, was adopted because bacterial growth is stimulated when yeast growth is limited by nutritional deficiency of the broth. According to Oliva-Neto \& Yokoya (1997) the bacterial growth is stimulated when the sugar content of the medium falls below $50 \mathrm{~g} \mathrm{~L}^{-1}$.

The fermentation inoculum was prepared suspending $15.0 \mathrm{~g}$ of the yeast Saccharomyces cerevisiae "Fleischmann" (Fleischmann \& Royal Ltda) in $25.0 \mathrm{~mL}$ of sterilized, distilled water. The $\mathrm{pH}$ was adjusted to 2.5 and held under agitation for $1 \mathrm{~h}$, to mimic industry treatment.

The musts $(120 \mathrm{~mL})$ were inoculated with the bacterial cultures at a level of $1 \%\left(\mathrm{v} \mathrm{v}^{-1}\right)$, incubated at $32^{\circ} \mathrm{C}$ for $24 \mathrm{~h}$ for the growth of the bacteria, and then irradiated with gamma radiation at doses of 2.0, 4.0, 6.0, 8.0 and $10.0 \mathrm{kGy}$, at a rate of $2.0 \mathrm{kGy} \mathrm{h}^{-1}$. The gamma rays came from a panoramic ${ }^{60} \mathrm{Cobalt}$ source (Nordion Canadian Gammabeam 650 Irradiator, with an activity of $7.4 \times 10^{13} \mathrm{~Bq}$. The programmed dose of radiation was controlled by removing the sample from the radiation source at the appropriate time and the real dose of radiation absorbed by the samples was measured by Amber 3042 poly-methylmethacrylate dosimeters.

Bacterial count was accomplished by serial dilutions and then pour-plated on triplicate on plates with solid PCA (Difco) for bacilli and solid MRSA (Difco) for lactobacilli. Solid MRSA for the bacterial count of the mixed culture and the natural microbial flora of the sugarcane juice was also used. Plates were incubated at $32^{\circ} \mathrm{C}$ for $48 \mathrm{~h}$. Results were expressed as CFU mL ${ }^{-1}$ (Oliveira et al., 1996).

An aliquot of $5.0 \mathrm{~mL}$ of the yeast inoculhm was added to $80.0 \mathrm{~mL}$ of irradiated must and the fermentation was carried out for $12 \mathrm{~h}$ in a shaker $\left(100 \mathrm{rev} \mathrm{min}^{-1}\right)$ at $32^{\circ} \mathrm{C}$. The concentration of yeast cells was $22 \mathrm{~g} \mathrm{~L}^{-1}$ of wet weight, corresponding to $6.7 \mathrm{~g} \mathrm{~L}^{-1}$ of dry weight.

Determination of cellular viability of yeast was carried out on the fermented musts (wines). The cells were observed under light field microscope using eritrosine to differentiate living and dead cells (Oliveira et al., 1996). The determination of the total acidity of the wines was based on procedures described by Zago et al. (1996). Their volatile acidity was determined according to Joslyn (1970). The ethanol yield was calculated based on the concentration of ethanol of the wines, determined according to Joslyn (1970).

The experimental design consisted of three randomized blocks, with one replicate in each block. Statistical studies (Hartley test, $\mathrm{F}$ test and polynomial regression analysis) were performed with the aid of the statistical software SAS (1990) $(\alpha=0.05)$.

\section{RESULTS AND DISCUSSION}

The variability of the real dose of radiation absorbed by the samples was less than $3 \%$ of the programmed dose (data not shown). The dosimeters also detected the homogeneity of the dose and validated the irradiation process.

The bacterial count of the must decreased as the dose of radiation increased (Figure 1). As the lactobacilli were completely inactivated at the lowest radiation doses, it was decided to carry out another experiment modify- 
ing the range and the scale of the doses of radiation applied to the musts contaminated with these bacteria. These new curves of inactivation (Figure 2) were useful for a more accurate determination of the $\mathrm{D}_{10}$ values (dose of radiation to decrease a logarithmical cycle in the microorganism population) for these bacteria.

Several authors have also observed reduction of the bacterial population by ionizing radiation. Ostapenkov \& Matison (1975), in the sterilization of molasses with high frequency waves; Giorgi \& Gontier (1979), in the preservation of syrup (65\% of soluble solids) with ultraviolet radiation; Iizuka et al. (1968), in the reduction of two logarithmical cycles of the microbial contamination of molasses irradiated with $0.6 \mathrm{kGy}$ of gamma radiation; Acosta \& Lodos (1982), who determined the $\mathrm{D}_{10}$ values of 0.30 and $0.45 \mathrm{kGy}$ for Leuconostoc mesenteroides in sugarcane and in sugarcane juice, respectively; Zeller et al. (1984), in sterilization and conservation of sugarcane syrup with doses of gamma radiation above $10 \mathrm{kGy}$; and Postmes et al. (1995), in sterilization of honey contaminated with Clostridium botulinum and Bacillus subtilis by gamma radiation.

The $\mathrm{D}_{10}$ values (in kGy) obtained from the reciprocal of the linear regression slopes of the log survivor values were: Bacillus subtilis: 1.36, Bacillus coagulans: 1.45, Lactobacillus plantarum: 0.56, Lactobacillus

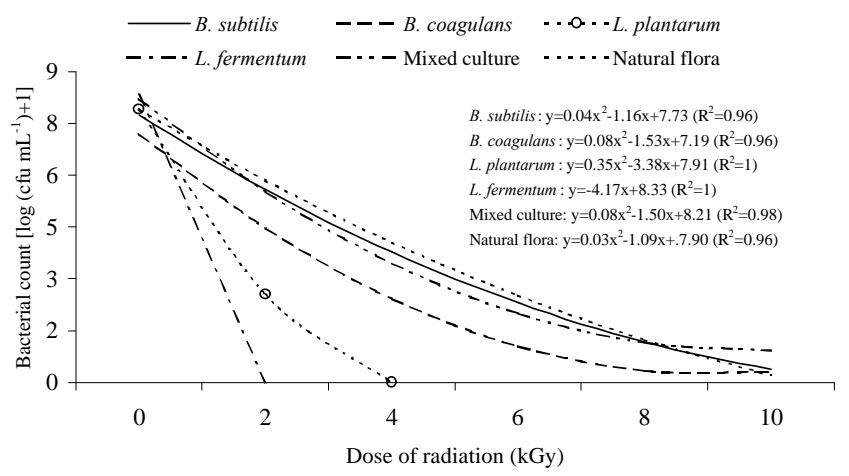

Figure 1 - Effect of the radiation doses on bacterial count of the must from sugarcane juice inoculated with bacteria.

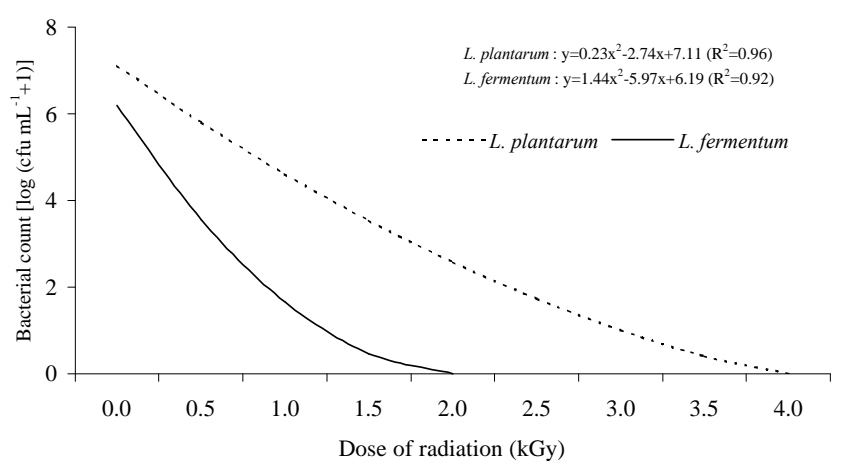

Figure 2 - Bacterial count of musts inoculated with Lactobacillus plantarum e Lactobacillus fermentum and irradiated with doses of gamma radiation $(\mathrm{kGy})$. fermentum: 0.32 , mixed bacterial culture: 1.37 ; and natural flora of the sugarcane juice: 1.30 .

Bacillus presented higher $\mathrm{D}_{10}$ values than Lactobacillus because bacilli are sporulating bacteria. Urbain (1986) found $\mathrm{D}_{10}$ values between 0.35 and 2.60 kGy for B. subtilis in several substrata, and Huhtanen (1991) found $\mathrm{D}_{10}$ value of $1.43 \mathrm{kGy}$ for $B$. subtilis in sugar syrup. The $\mathrm{D}_{10}$ value for $B$. coagulans in nutrient broth was $1.29 \mathrm{kGy}$ (Urbain, 1986). Byun et al. (1989), studying the gamma radiation in reducing the lactic acid bacteria associated with Kimchi fermentation, obtained a mean $\mathrm{D}_{10}$ value of $0.60 \mathrm{kGy}$ for some lactobacilli.

The concentration of total reducing sugars of the must was stable for radiation doses up to $10.0 \mathrm{kGy}$ (data not shown). This is a very important point because any method of decontamination should not degrade the sugars of the sugarcane must in order to not decrease the ethanol yield. Beyers (1980) did not find a drop in the concentration of total sugars of several kind of foods treated with doses of gamma radiation up to $30 \mathrm{kGy}$. Zeller et al. (1984), and Watanabe \& Sato (1980) also observed stability in the concentration of the total sugars of sugarcane syrups and molasses submitted to doses of gamma radiation of 30 and $40 \mathrm{kGy}$, respectively.

The irradiated musts did not appear to cause damage to the fermentation process. The same was observed by Vajda \& Gal (1970) in musts prepared from granulated sugar irradiated with doses up to $20 \mathrm{kGy}$; by Zeller et al. (1984), in musts prepared from sugarcane syrups irradiated with the dose of $10 \mathrm{kGy}$; by Samuta et al. (1997), in musts prepared from irradiated rice; and by Iizuka et al. (1968), in musts prepared from molasses irradiated with the dose of $0.6 \mathrm{kGy}$.

In general, the total acidity (Figure 3 ) and the volatile acidity (Figure 4) produced during the fermentation decreased as the dose of radiation increased. The total and volatile acidity produced during the fermentation of the musts contaminated with bacilli was higher than those produced during the fermentation of the musts contaminated with lactobacilli. The fermentations contaminated with Lactobacillus fermentum produced the lowest total acidity (Figure 3). The fermentation of the must contaminated with Lactobacillus plantarum produced the lowest volatile acidity (Figure $4)$.

The viability of the yeast represents the rate of living cells. The viability of the yeast in must previously irradiated revealed a slightly increase as the dose of radiation increased up to $6.0 \mathrm{kGy}$ (Figure 5), stabilizing at dose levels above this value. The presence of Bacillus subtilis did not affect the viability of the yeast.

The natural microbial flora of the must had the highest influence in decreasing yeast viability. This must have resulted from the fact that sugarcane juice presents great diversity of contaminating microorganisms and 
some of them might have originated a more severe inhibitory effect in the yeast.

The ethanol yield increased as the radiation dose increased (Figure 6). Iizuka et al. (1968) observed increase in the ethanol yield for fermentations of musts prepared from molasses irradiated with doses up to $0.6 \mathrm{kGy}$. The ethanol yield may decrease when bacterial contamination reaches levels above $10^{7} \mathrm{CFU} \mathrm{mL}^{-1}$ (Amorim et al., 1981).

In the present research, in general, the fermentation of the non-irradiated must presented a decrease of approximately $1.9 \%$ in its ethanol yield as compared to

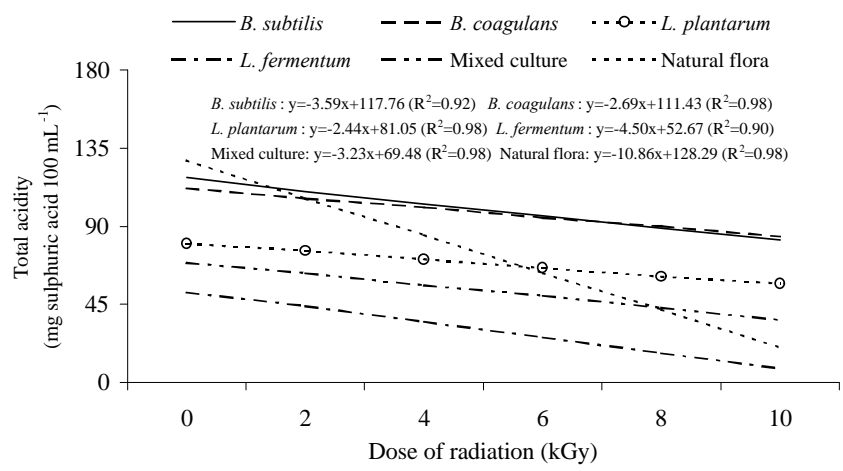

Figure 3 - Total acidity produced during the fermentation of irradiated sugarcane must inoculated with bacteria.

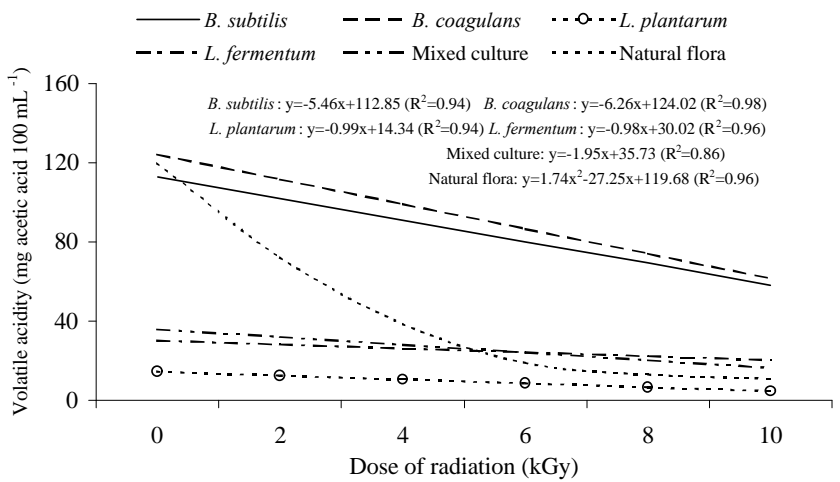

Figure 4 - Volatile acidity formed during the fermentation of irradiated sugarcane must contaminated with bacteria.

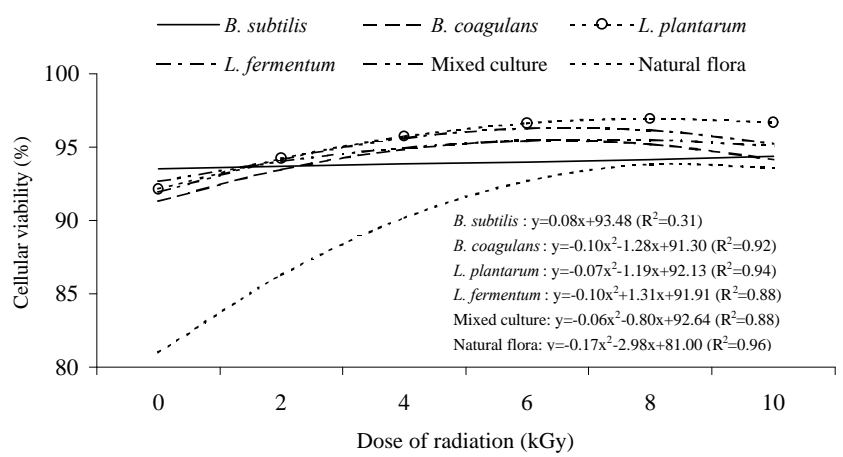

Figure 5 - Viability of the yeast in must inoculated with different bacteria and irradiated at doses of gamma radiation.

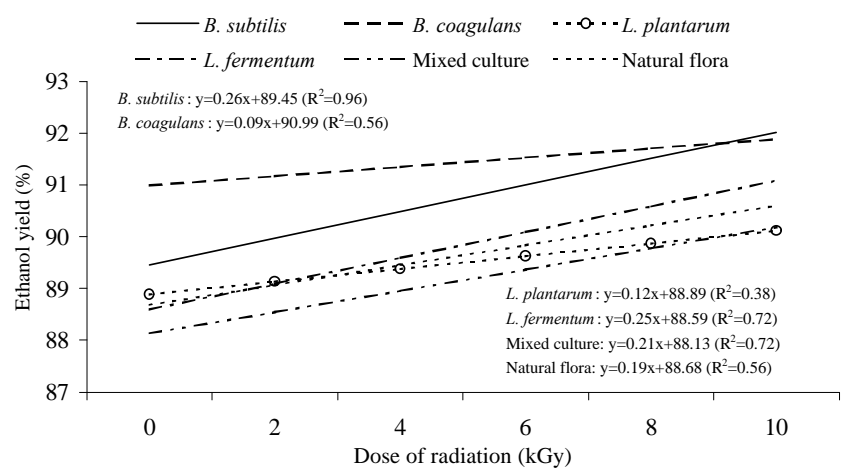

Figure 6 - Effect of radiation doses on ethanol yield (\%) of fermentations of musts from sugarcane juice contaminated with bacteria.

the fermentation of the must irradiated with the dose of $10.0 \mathrm{kGy}$ (Figure 6). This drop in the ethanol yield caused by the bacterial contamination was lower than values found by some authors. The bacterial contamination may cause losses of up to $55 \%$ of the theoretical value in the process of ethanol production (Amorim et al., 1981). Althertum et al. (1984) verified a decrease of 14 to $90 \%$ in ethanol yield for fermentations contaminated with $10^{8}$ to $10^{9} \mathrm{CFU} \mathrm{mL}{ }^{-1}$ of bacteria. Khan \& Hoq (1990) reported that fermentations with bacterial contamination of $10^{6}$ $\mathrm{CFU} \mathrm{mL} \mathrm{mL}^{-1}$, of which $10^{3} \mathrm{CFU} \mathrm{mL}{ }^{-1}$ were high producers of acid, presented $11 \%$ lower ethanol yield. Essia-Ngang et al. (1989) found a decrease of $30 \%$ in the ethanol yield of fermentations in which the concentration of lactic acid reached $5.0 \mathrm{~g} \mathrm{~L}^{-1}$.

The irradiation of the must originated indirect beneficial effect to the yeast. The treatment with gamma radiation reduced the bacterial load of the sugarcane must, decreasing the acidity of the medium and increasing the viability of the yeast culture afterwards added to perform fermentation. The growth of the yeast is inhibited by organic acids and toxins produced by bacterial activity (Amorim \& Oliveira, 1982; Oliva-Neto \& Yokoya, 1997).

The relative cost-benefit of the irradiation of sugarcane must can be evaluated in light of the increase of the ethanol yield with the irradiation of the must - 1.9\%, as obtained herein; annual volume of ethanol produced by a large industry - 200 million liters; price paid to the industry for a liter of ethanol - US\$ 0.20 (CEPEA, 2002); cost of an installed and ready to operate irradiator in this industry - US\$ 1.9 millions. These numbers indicate that within two and half years the investment in the irradiator would be paid by the profit coming from the increment of the ethanol production originated from the irradiation of the sugarcane must.

The irradiation of a typical must of the industry (approximately 15\% total reducing sugars) could provide higher reductions of the population of the contaminants, because the bacteria would be in a more unfavourable 
medium (see $M \& M$, Fermentative broth, $2^{\text {nd }}$ paragraph), and so they could be more sensitive to the inactivation by the radiation.

\section{CONCLUSION}

Gamma irradiation was efficient in reducing microbial contamination of sugarcane must and improved some biochemical and microbiological parameters of the yeast-based ethanolic fermentation, including an increase of $1.9 \%$ in ethanol yield.

\section{REFERENCES}

ACOSTA, S.; LODOS, J. The action of gamma radiation on sugarcane as a new sterilization method. Sugar y Azucar, v.77, p.55-59, 1982.

ALCARDE, A.R.; WALDER, J.M.M.; HORII, J. Comparison between gamma radiation and Kamoran $\mathrm{HJ}$ in the decontamination of sugar-cane must. Journal of Food Processing and Preservation, v.25, p.137-147, 2001.

ALTERTHUM, F.; CRUZ, M.R.M.; VAIRO, M.L.R.; GAMBASSI, D.M. Efeito dos microrganismos contaminantes da fermentação alcoólica nas microdestilarias. STAB - Açúcar, Álcool e Subprodutos, v.3, p.42-49, 1984.

ALVES, D.M.G. Fatores que afetam a formação de ácidos orgânicos bem como outros parâmetros da fermentação alcoólica. Piracicaba: USP/ ESALQ, 1994. 251p. (Dissertação - Mestrado)

AMORIM, H.V.; OLIVEIRA, A.J. Infecção na fermentação: como evitála. Álcool e Açúcar, v.2, p.12-18, 1982.

AMORIM, H.V.; OLIVEIRA, A.J.; CAMPOS, H. Infecção, problema sério na produção de álcool. In: CONGRESSO NACIONAL DA SOCIEDADE DOS TÉCNICOS AÇUCAREIROS DO BRASIL, 2., Rio de Janeiro, 1981. Anais. Piracicaba: STAB, 1981. p.158-168.

BEVAN, D.; BOND, J. Microorganism in field and mill - a preliminary survey. In: CONFERENCE OF THE QUEENSLAND SOCIETY OF SUGAR CANE TECHNOLOGISTS, 38., Cairns, 1971. Proceedings. Brisbane: Watson Fergunson, 1971. p.137-143.

BEYERS, M. The influence of radiation on the chemical constituents of food. Food Irradiation Information, v.10, p.17-24, 1980.

BYUN, M.W.; CHA, B.S.; KWON, J.H.; CHO, H.O.; KUM, W.J. The combined effect of heat treatment and irradiation on the inactivation of major lactic acid bacteria associated with Kimchi fermentation. Korean Journal of Food Science and Technology, v.21, p.185-191, 1989.

CENTRO DE ESTUDOS AVANÇADOS EM ECONOMIA APLICADA CEPEA. Indicadores de preços - Álcool. http:// www.cepea.esalq.usp.br/ (11 nov. 2002)

ESSIA-NGANG, T.J.E.; LETOURNEAU, F.; VILLA, P. Alcoholic fermentation of beet molasses: effects of lactic acid on yeast fermentation parameters. Applied Microbiology and Biotechnology, v.31, p.125128,1989

GALLO, C.R.; CANHOS, V.P. Contaminantes bacterianos na fermentacao alcoólica: revisão. STAB - Açúcar, Álcool e Subprodutos, v.9, p.3540, 1991

GIORGI, J.C.; GONTIER, R. Preservation of pure sugar syrups by ultraviolet irradiation. Sucre Française, v.120, p.107-109, 1979.
HUHTANEN, C.N. Gamma radiation resistance of Clostridium botulinum $62 \mathrm{~A}$ and Bacillus subtilis spores in honey. Journal of Food Protection, v.54, p.894-896, 1991.

IIZUKA, H.; SHIBABE, S.; ITO, H. Effect of gamma irradiation on fermentation media consisting mainly of cane molasses. Food Irradiation, v.3, p.116-122, 1968.

JOSLYN, M.A. Alcoholometry. In: JOSLYN, M.A. (Ed.) Methods in food analysis: physical, chemical and instrumental methods of analysis. New York: Academic Press, 1970. cap.11, p.447-474.

KHAN, A.R.; HOQ, M.M. Lactic acid bacteria as contaminant in alcohol fermentation. Bangladesh Journal of Microbiology, v.7, p.119-121, 1990.

OLIVA-NETO, P.; YOKOYA, F. Effects of nutritional factors on growth of Lactobacillus fermentum mixed with Saccharomyces cerevisiae in alcoholic fermentation. Revista de Microbiologia, v.28, p.25-31, 1997.

OLIVEIRA, A.J.; GALLO, C.R.; ALCARDE, V.E.; GODOY, A.; AMORIM, H.V. Métodos para o controle microbiológico na produção de álcool e açúcar. 2.ed. Piracicaba: FERMENTEC; FEALQ; ESALQ/USP, 1996. $89 \mathrm{p}$.

OSTAPENKOV, A.M.; MATISON, V.A. Sterilization of molasses in ultrahigh frequency electromagnetic fields. Izvestiya Vysshikh Tekhnologiya, v.6, p.77-79, 1975.

POSTMES, T.; BOGAARD, A.E.; HAZEN, M. The sterilization of honey with cobalt-60 gamma radiation: a study of honey spiked with spores of Clostridium botulinum and Bacillus subtilis. Experientia, v.51, p.986989, 1995.

ROSALES, S.Y.R. Contaminantes bacterianos da fermentação etanólica: isolamento em meios diferenciais, identificação e avaliação de desinfetantes. Rio Claro: UNESP/IB, 1989. 200p. (Tese - Doutorado).

SAMUTA, T.; ARAMAKI, I.; HASHIZUME, K. Production of sake from rice material exposed to gamma radiation and technical development for its production: characterization of low-dose exposed rice and smallscale brewing with it. Kokuritsu Kikan Genshiryoku Shiken Kenkyu Seika Hokoku-Sho, v.36, p.24-26, 1997.

SAS INSTITUTE. SAS users guide: statistic. 6.ed. Cary: Statistical Analysis System Institute, 1990. 584p.

URBAIN, W.M. Food irradiation. Orlando: Academic Press, 1986. 351p. VAJDA, O.; GAL, I. Microbiological study of irradiated sugar. Elelmiszervizsgalati Koezlemenyek, v.16, p.129-135, 1970.

WATANABE, H.; SATO, T. Changes in content and composition of sugar in molasses caused by gamma irradiation. Journal of Fermentation Technology, v.58, p.363-366, 1980.

ZAGO, E.A.; SILVA, L.F.L.F.; BERNARDINO, C.D.; AMORIM, H.V Métodos analíticos para o controle da produção de álcool e açúcar 2.ed. Piracicaba: FERMENTEC; FEALQ; ESALQ/USP, 1996. 194p.

ZELLER, A.L.V.; OLIVEIRA, A.J.; ZAGO, E.A. Conservação de xarope de cana-de-açúcar pelo emprego da radiação gama. STAB - Açúcar, Álcool e Subprodutos, v.2, p.29-36, 1984.

Received January 06,2003

Accepted August 27, 2003 